\title{
ROLA INSPEKCJI TRANSPORTU DROGOWEGO W OGRANICZENIU WYPADKÓW W RUCHU DROGOWYM W POLSCE
}

Streszczenie. W 2001 r. powołano jednostkę Inspekcji Transportu Drogowego (ITD), której celem jest zwiększenie bezpieczeństwa w ruchu drogowym.

Celem artykułu jest odpowiedź na pytanie, na ile powołanie ITD przyczynia się do polepszenia bezpieczeństwa ruchu drogowego w Polsce. W artykule oprócz naświetlenia celów ITD, organizacji skali wypadków z udziałem ciężarowych pojazdów samochodowych, omawiamy stan ilościowy przeprowadzonych kontroli. Obserwacją obejmujemy lata 2005-2012. Artykuł pokazuje, że dzięki ostrym decyzjom administracyjnym i karnym stopniowo zmniejsza się liczba wypadków i ich skutków z udziałem ciężarowych pojazdów samochodowych.

Słowa kluczowe: pojazdy ciężarowe, wypadki, Inspekcja Transportu Drogowego.

JEL: R42.

\section{POSTAWIENIE PROBLEMU}

Konieczność zachowania porządku, ochrony środowiska oraz bezpieczeństwa, a także uczciwej konkurencji w ruchu drogowym przyczyniły się do powstania Inspekcji Transportu Drogowego (ITD). Jednostkę tę powołano do życia zgodnie z ustawą o transporcie drogowym z dnia 6 IX 2001 r. Powstanie ITD było również związane z przystąpieniem Polski do Unii Europejskiej i było wymogiem akcesyjnym gwarantującym wiarygodność państwa graniczącego z Unią. Zadaniem ITD była kontrola przede wszystkim pojazdów ciężarowych, specjalistycznych w ruchu krajowym i międzynarodowym. Z punktu widzenia zakładów ubezpieczeń zastanawiamy się, na ile ta instytucja przyczyniła się do zmniejszenia liczby wypadków drogowych z udziałem samochodów ciężarowych? Ma to znaczenie w zakresie roszczeń związanych ze szkodami osobowymi, wypłatami za szkody materialne oraz w przewożonych towarach.

Celem artykułu jest przedstawienie efektów funkcjonowania inspekcji transportu drogowego w latach 2005-2012. W artykule nawiązujemy do ubezpieczeń komunikacyjnych w świetle uzyskanych efektów.

* Uniwersytet Łódzki, Wydział Ekonomiczno-Socjologiczny, Katedra Ubezpieczeń, stanislaw.wieteska@uni.lodz.pl 
W artykule obejmujemy analizą dostępne dane statystyczne. Artykuł napisano w oparciu o załączoną literaturę przedmiotu.

\section{CELE I ZADANIA INSPEKCJI TRANSPORTU DROGOWEGO}

Działalność ITD początkowo dotyczyła badań stanu technicznego oraz kontroli pojazdów przewożących materiały niebezpieczne. W kolejnych latach zwiększano zakres zadań i kompetencje inspektorów wykonujących kontrole w ruchu drogowym. Już w 2004 r. wprowadzono kontrolę ciśnieniowych urządzeń transportowych. Równocześnie w tym czasie instytucja ITD przystąpiła do Europejskiej Kontroli Drogowej (Euro Controle Route). Jest to organizacja międzynarodowa zrzeszająca państwa UE. Europejska Kontrola Drogowa zajmuje się wymianą informacji, prowadzeniem szkoleń przeznaczonych dla inspektorów oraz koordynacją działań kontrolnych. Ma to na celu nie tylko poprawę bezpieczeństwa drogowego, ale i stworzenie ram prawnych do uczciwej konkurencji w transporcie drogowym Już w 2005 r. rozszerzono zakres zadań ITD o kontrolę używanego paliwa.

Od 1 I 2011 r. ITD dostała kompetencje uprawniające do kontroli samochodów osobowych w przypadku gdy:

- kierujący samochodem osobowym doprowadził do spowodowania bezpośredniego zagrożenia bezpieczeństwa;

- zarejestrowano przy użyciu przyrządów rejestrujących lub kontrolnopomiarowych naruszenia przepisów o ruchu drogowym;

- istnieje podejrzenie, że kierujący pojazdem może być pod wpływem alkoholu lub środka odurzającego;

- stwierdzono rażące naruszenia przepisów ruchu drogowego (Żaczek 2014).

W dniu 30 XII 2010 r. na mocy zarządzenia nr 103 Prezesa Rady Ministrów nadano nowy statut Głównej Inspekcji Transportu Drogowego oraz utworzono Centrum Automatycznego Nadzoru nad Ruchem Drogowym (CANARD). Jest to jednostka bezpośrednio odpowiadająca za zarządzanie systemem automatycznej rejestracji wykroczeń. Z kolei Biuro do spraw Elektronicznego Poboru Opłat (BEPO) odpowiedzialne jest za realizację zadań wynikających z ustawy o drogach publicznych. Obecnie w ramach CANARD zainstalowanych jest ok. 210 urządzeń Fotorapid CM oraz 90 urządzeń Multaradar CD.

Należy zwrócić uwagę, że nadanie dodatkowych uprawnień musi być zgodne z prawem (Szymaniak 2013).

Do głównych zadań ITD należy zaliczyć:

- podwyższanie jakości usług świadczonych przez transport drogowy (np. kontrola stanu technicznego pojazdów przewożących zwierzęta, towary niebezpieczne, towary łatwo psujące się); 
- podwyższanie jakości infrastruktury drogowej (np. kontrola opłat, wskazywanie na miejsca najbardziej niebezpieczne);

- kontrola tachografów (Duś, Duś-Pilarz 2009: 263-274);

- kontrola dopuszczenia pojazdów do ruchu ${ }^{1}$;

- bezpieczeństwo warunków pracy kierowców (np. nadzór nad stanem technicznym, kontrola czasu pracy) ${ }^{2}$;

- kontrola przestrzegania ochrony środowiska naturalnego (np. ograniczania emisji spalin);

- kontrole ciężaru pojazdów (tzw. dopuszczalnej masy całkowitej pojazdu) (Szwed 2014: 40; Wardęga 2010: 400-401; Ryś 2012: 400-404) i ponadnormatywnych wymiarów (Ważenie pojazdów... 2002: 41);

- wpływ na bezpieczeństwo w ruchu drogowym (kontrola: dokumentacji, przepisów, sprawdzanie zgodności);

- działalność informacyjna w zakresie bezpieczeństwa ruchu drogowego;

- kontrola pojazdów przewożących materiały niebezpieczne (Kacprzyk 2010);

- kontrola pojazdów w przewozie osobowym (Burski, Krassowski 2009: 30-37 oraz Inspektor drogowy... 2011: 76-77);

- współdziałanie $\mathrm{z}$ instytucjami bezpieczeństwa ${ }^{3}$;

- współdziałanie $\mathrm{z}$ wojewodami ${ }^{4}, \quad \mathrm{z}$ centralną ewidencją pojazdów (www.gitd.gov.pl. Rzeczp. Nr 50-DA).

Struktura organizacyjna GITD została określona poprzez wprowadzenie regulaminu $^{5}$, w którym uregulowano m.in. zasady funkcjonowania Biura Nadzoru Inspekcyjnego. Na szczeblu wojewódzkim znajdują się Wojewódzkie Inspektoraty Transportu Drogowego.

${ }^{1}$ Obwieszczenie Ministra Transportu z 8 lipca 2007 r. w sprawie szczegółowych czynności organów w sprawach związanych $\mathrm{z}$ dopuszczeniem pojazdu do ruchu oraz wzorców dokumentów w tych sprawach (Dz.U. 2007 poz. 968 w z późn. zm.).

${ }^{2}$ Zarządzenie nr 21/2011 Głównego Inspektora Transportu Drogowego z 31 III 2011 r. w sprawie określenia wysokości współczynnika ryzyka, występowania naruszeń dotyczących czasu prowadzenia pojazdu, obowiązkowych przerw i czasu odpoczynku kierowców za rok 2010, Dziennik Urzędowy Ministra Infrastruktury nr 4/2011, poz. 26.

${ }^{3}$ Rozporządzenie Ministra Infrastruktury z dnia 29 września 2004 r. w sprawie współdziałania straży ochrony kolei, z Policją, Strażą Graniczną i Inspekcją Transportu Drogowego, Dziennik Ustaw nr 223/2004, poz. 2262.

${ }^{4}$ Opublikowana ustawa z dnia 3 sierpnia 2010 r. o zmianie ustawy o transporcie drogowym (Dz.U. nr 164/2010, poz. 1107-DA). Na mocy tej ustawy wojewodowie zostali zobowiązani do przekazania wag stacjonarnych do kontroli pojazdów przez ITD (Biuletyn PISIL 5/2010, s. 6).

${ }^{5}$ Zarządzenie nr 12/2011 Głównego Inspektora Transportu Drogowego z dnia 16 lutego $2011 \mathrm{r}$. w sprawie nadania regulaminu organizacyjnego Głównemu Inspektorowi Transportu Drogowego, Dziennik Urzędowy Ministra Infrastruktury nr 2/2011, poz. 11. 


\section{PODSTAWOWE AKTY PRAWNE}

Dynamiczny rozwój transportu w Europie spowodował, że na szczeblu UE wprowadzono wiele aktów prawnych regulujących ruch drogowy. Do najważniejszych zaliczyć możemy:

1. Dyrektywa 2002/15/WE Parlamentu Europejskiego i Rady z dnia 11 marca 2002 r. w sprawie organizacji czasu pracy osób wykonujących czynności w trasie w zakresie transportu drogowego.

2. Oświadczenie Rządowe z dnia 24 września 1984 r. w sprawie przystąpienia Polskiej Rzeczypospolitej Ludowej do Umowy o międzynarodowych przewozach szybko psujących się artykułów żywnościowych i o specjalnych środkach transportu przeznaczonych do tych przewozów (ATP), sporządzonej w Genewie dnia 1 września 1970 r. (Dz.U. z 1984 r. nr 49, poz. 254).

3. Oświadczenie Rządowe z dnia 30 sierpnia 1999 r. w sprawie ratyfikacji przez Rzeczypospolitą Polską umowy europejskiej dotyczącej pracy załóg pojazdów wykonujących międzynarodowe przewozy drogowe (AETR), sporządzonej w Genewie dnia 1 lipca 1970 r., oraz ogłoszenia jednolitego tekstu tej umowy (Dz.U. z 1999 r. nr 94, poz. 1087).

4. Oświadczenie Rządowe z dnia 16 stycznia 2009 r. w sprawie wejścia w życie zmian do załączników A i B umowy europejskiej dotyczącej międzynarodowego przewozu drogowego towarów niebezpiecznych (ADR), sporządzonej w Genewie dnia 30 września 1957 r. (Dz.U. z 2009 r. nr 27, poz. 162).

Bezpośrednimi konsekwencjami uregulowań unijnych są w Polsce odpowiednie akty prawne. Część z nich dotyczy funkcjonowania ITD w Polsce. Do najważniejszych należy zaliczyć:

1. Ustawa z dnia 6 września 2001 r. o transporcie drogowym (tekst jednolity Dz.U. z 2013 r. poz. 1414).

2. Ustawa z dnia 16 kwietnia 2004 r. o czasie pracy kierowców (tekst jednolity Dz.U. z 2012 r. poz. 1155).

3. Ustawa z dnia 29 lipca 2005 r. o systemie tachografów cyfrowych (Dz.U. z 2005 r. nr 180 poz. 1494 z późn. zm.).

4. Rozporządzenie Ministra Transportu w sprawie okresowych ograniczeń oraz zakazu ruchu niektórych rodzajów pojazdów na drogach z dnia 31 lipca 2007 r. (Dz.U. z 2007 r. nr 147 poz. 1040).

5. Rozporządzenie Ministra Spraw Wewnętrznych i Administracji z dnia 18 lipca 2008 r. w sprawie kontroli ruchu drogowego (z późn. zm).

6. Rozporządzenie Ministra Infrastruktury z dnia 5 czerwca 2009 r. w sprawie opłat za przejazd po drogach krajowych (Dz.U. z 2009 r. nr 86, poz. 72 z późn. zm.).

7. Rozporządzenie Ministra Infrastruktury z dnia 2 września 2009 r. w sprawie kontroli przewozu drogowego (Dz.U. z 2009 r., nr 145, poz. 1184 z późn. zm). 
8. Zarządzenie nr 50/2011 Głównego Inspektora Transportu Drogowego $\mathrm{z}$ dnia 16 listopada $2011 \mathrm{r}$. w sprawie zasad prowadzenia kontroli przez inspektorów Inspekcji Transportu Drogowego (wraz z późniejszymi zmianami).

9. Obwieszczenie Marszałka Sejmu Rzeczypospolitej Polskiej z 15 października 2013 r. w sprawie ogłoszenia jednolitego tekstu ustawy o transporcie drogowym (Dz.U. z 2 grudnia 2013 r,. poz. 1414, rozdział 9 dotyczący Inspekcji Transportu Drogowego).

Łatwo zauważyć, że ustawodawca ww. aktów prawnych swoimi ustaleniami przyczynia się do wzrostu bezpieczeństwa w ruchu drogowym.

\section{WYPADKI SPOWODOWANE SAMOCHODAMI CIĘŻAROWYMI}

Wypadek drogowy zgodnie z definicją Biura Prewencji Ruchu drogowego to „niedające się przewidzieć zdarzenie mające miejsce w ruchu drogowym pozostające w związku przyczynowym $\mathrm{z}$ ruchem drogowym, wynikające $\mathrm{z}$ naruszenia zasad bezpieczeństwa obowiązujących w tym ruchu, którego skutkiem są nieumyślne obrażenia ciała powodujące naruszenie czynności narządu ciała lub rozstroju zdrowia trwający dłużej niż 7 dni (średnio ciężki wypadek drogowy) śmierć albo ciężki uszczerbek na zdrowiu (ciężki wypadek drogowy)" (Reichel, Nowakowski 2006: 103).

Skalę wypadków drogowych z udziałem pojazdów ciężarowych przedstawia Tabela 1.

Tabela 1. Liczba samochodów ciężarowych oraz liczba wypadków spowodowanych z udziałem pojazdów ciężarowych w latach 2002-2012

\begin{tabular}{|c|c|c|c|c|}
\hline Lata & $\begin{array}{c}\text { Liczba samochodów } \\
\text { ciężarowych }\end{array}$ & Wypadki & Zabici & Ranni \\
\hline 2002 & 2162614 & 4243 & 577 & 5659 \\
\hline 2003 & 2191762 & 4298 & 552 & 5670 \\
\hline 2004 & 2262923 & 4349 & 545 & 5751 \\
\hline 2005 & 2177901 & 3920 & 494 & 5125 \\
\hline 2006 & 2246294 & 3936 & 484 & 5292 \\
\hline 2007 & 2345068 & 3387 & 383 & 4597 \\
\hline 2008 & 2511677 & 2864 & 341 & 3815 \\
\hline 2009 & 2595485 & 2495 & 280 & 3432 \\
\hline 2010 & 2767035 & 2394 & 292 & 3157 \\
\hline 2011 & 2892064 & 2341 & 288 & 3023 \\
\hline 2012 & 2920779 & 2096 & 235 & 2722 \\
\hline
\end{tabular}

Źródło: Opracowanie własne na podstawie raportów policyjnych z lat 2002-2012 
$\mathrm{Z}$ danych zawartych w Tabeli 1 widzimy, że liczba samochodów ciężarowych w badanym okresie wzrosła o ok. 35\%. Obserwujemy stopniowe zmniejszanie się liczby wypadków i ich skutków z udziałem samochodów ciężarowych. Warto także zwrócić uwagę na dwa rodzaje samochodów ciężarowych (Tabela 2).

Tabela 2. Wypadki z udziałem samochodów ciężarowych bez przyczep i z przyczepą (2013 r.)

\begin{tabular}{|l|l|c|c|c|}
\hline Wyszczególnienie & \multicolumn{1}{|c|}{ Obciążenie } & Ilość wypadków & Zabici & Ranni \\
\hline \multirow{2}{*}{$\begin{array}{l}\text { Samochód } \\
\text { ciężarowy }\end{array}$} & bez przyczep & 1259 & 133 & 1575 \\
\cline { 2 - 5 } & z przyczepami & 695 & 92 & 902 \\
\hline
\end{tabular}

Źródło: Wypadki drogowe w 2013 r., „Miesięcznik Ubezpieczeniowy” 6/2014, wkładka.

$\mathrm{Z}$ danych zawartych w tab. 2 widzimy, że najwięcej wypadków powodują samochody ciężarowe bez przyczepy.

\section{KONTROLE ITD I ICH REZULTATY}

Corocznie inspektorzy ITD dokonują wielu kontroli pojazdów ciężarowych na terenie wszystkich województw (Tabela 3).

$\mathrm{Z}$ danych zawartych w Tabeli 3 wynika, że średnio rocznie w Polsce przeprowadza się ok. 176 tys. kontroli. Najwięcej kontroli (średnio) przeprowadzono w województwach: śląskim, mazowieckim, podkarpackim, wielkopolskim. Jak łatwo zauważyć, najwięcej kontroli przeprowadza się w województwach w których występuje zwiększony ruch pojazdów ciężarowych. Postawmy obecnie pytanie, jakie są rezultaty kontroli ITD (Tabela 4).

Tabela 3. Ogólna liczba kontroli drogowych ITD w zakresie realizacji standardów UE w ujęciu regionalnym RP w latach 2005-2012

\begin{tabular}{|c|c|c|c|c|c|c|c|}
\hline \multirow{2}{*}{ Województwo } & \multicolumn{7}{|c|}{ Liczba przeprowadzonych kontroli drogowych } \\
\hline & 2005 & 2006 & 2007 & 2010 & 2011 & 2012 & Średnia \\
\hline 1 & 2 & 3 & 4 & 5 & 6 & 7 & 8 \\
\hline Dolnośląskie & 10661 & 10418 & 10987 & 14365 & 10955 & 14490 & 11979 \\
\hline Kujawsko-pomorskie & 8052 & 6140 & 6594 & 10161 & 9016 & 10135 & 8350 \\
\hline Lubelskie & 11757 & 10385 & 8644 & 12790 & 11502 & 13781 & 11477 \\
\hline Lubuskie & 7752 & 8563 & 11374 & 11991 & 10738 & 12921 & 10557 \\
\hline Łódzkie & 14955 & 13047 & 11107 & 13110 & 11304 & 13516 & 12840 \\
\hline
\end{tabular}


Tab. 3 (cd.)

\begin{tabular}{|l|r|r|r|r|r|r|r|}
\hline \multicolumn{1}{|c|}{1} & \multicolumn{1}{c|}{2} & \multicolumn{1}{c|}{3} & \multicolumn{1}{c|}{4} & \multicolumn{1}{c|}{5} & \multicolumn{1}{c|}{6} & \multicolumn{1}{c|}{7} & \multicolumn{1}{c|}{8} \\
\hline Małopolskie & 10527 & 11256 & 10858 & 13224 & 11191 & 15190 & 12041 \\
\hline Mazowieckie & 16450 & 13835 & 15075 & 22323 & 15023 & 15374 & 16347 \\
\hline Opolskie & 4859 & 5747 & 7461 & 7018 & 6055 & 6692 & 6305 \\
\hline Podkarpackie & 11136 & 13266 & 15058 & 17562 & 14095 & 13374 & 14082 \\
\hline Podlaskie & 8187 & 9216 & 10674 & 13818 & 9924 & 8866 & 10114 \\
\hline Pomorskie & 8712 & 7560 & 7753 & 8920 & 7354 & 7923 & 8037 \\
\hline Śląskie & 12121 & 16588 & 15389 & 19600 & 18522 & 19001 & 16870 \\
\hline Świętokrzyskie & 6068 & 6936 & 7904 & 8060 & 6792 & 7487 & 7208 \\
\hline Warmińsko-mazurskie & 6489 & 8115 & 7962 & 10033 & 9355 & 12487 & 9074 \\
\hline Wielkopolskie & 14503 & 13761 & 13662 & 14370 & 11292 & 16466 & 14009 \\
\hline Zachodniopomorskie & 5973 & 5434 & 5789 & 8021 & 7153 & 8063 & 6739 \\
\hline Razem & 158202 & 160267 & 166291 & 205366 & 170271 & 195766 & 176027 \\
\hline
\end{tabular}

Źródło: Sprawozdanie Gtównego Inspektora Transportu Drogowego za rok 2010, 2011, 2012 oraz Z. Burski, E. Krasowski, Analiza realizacji standardów ustawy o transporcie drogowym RP w aspekcie przewozu osobowego, Motrol 2009, 11B, s. 32 oraz Kacprzyk 2010.

$\mathrm{Z}$ danych zawartych w Tabeli 4 wynika, że w badanych latach średnie kwoty decyzji administracyjnych oraz mandatów karnych mają tendencję rosnącą. Oznacza to, że coraz bardziej restrykcyjna karno-administracyjna działalność inspektorów ITD przyczynia sie do zwiększenia bezpieczeństwa na drogach z udziałem transportu krajowego. Powyższy kierunek działań dotyczy wszystkich rodzajów pojazdów ciężarowych bez względu na kraj pochodzenia.

Tabela 4. Średnie kwoty nałożonych decyzji administracyjnych, średnie kwoty mandatów karnych wystawionych za naruszenie przepisów ruchu drogowego oraz średnie kwoty mandatów karnych za naruszenie przepisów o transporcie drogowym w latach 2010-2011 w Polsce (w zł)

\begin{tabular}{|l|c|c|}
\hline \multirow{2}{*}{ Wyszczególnienie } & 2010 & 2011 \\
\cline { 2 - 3 } & \multicolumn{1}{|c|}{ Średnie kwoty decyzji administracyjnych } \\
\hline 1 & 2 & 3 \\
\hline $\begin{array}{l}\text { Średnia kwota nałożonej decyzji admini- } \\
\text { stracyjnej }\end{array}$ & 2254 & 2348 \\
\hline $\begin{array}{l}\text { Średnia kwota decyzji administracyjnej } \\
\text { nałożonej na przewoźnika krajowego }\end{array}$ & 3141 & 3180 \\
\hline $\begin{array}{l}\text { Średnia kwota decyzji administracyjnej } \\
\text { nałożonej na przewoźnika zagranicznego }\end{array}$ & 1442 & 1502 \\
\hline & $\begin{array}{c}\text { Średnie kwoty mandatów karnych wystawionych za } \\
\text { naruszenie przepisów ruchu drogowego }\end{array}$ \\
\hline Średnia kwota wystawionego mandatu & 153 & 185 \\
\hline $\begin{array}{l}\text { Średnia kwota mandatu wystawionego na } \\
\text { przewoźnika krajowego }\end{array}$ & 159 & 191 \\
\hline
\end{tabular}


Tabela 4 (cd.)

\begin{tabular}{|l|c|c|}
\hline \multicolumn{1}{|c|}{1} & 2 & 3 \\
\hline $\begin{array}{l}\text { Średnia kwota mandatu wystawionego na } \\
\text { przewoźnika zagranicznego }\end{array}$ & 140 & 165 \\
\hline Średnia kwota wystawionego mandatu & \multicolumn{2}{|c|}{$\begin{array}{r}\text { Średnie kwoty mandatów karnych za naruszenie } \\
\text { przepisów o transporcie drogowym }\end{array}$} \\
\hline $\begin{array}{l}\text { Średnia kwota mandatu wystawionego na } \\
\text { przewoźnika krajowego }\end{array}$ & 260 & 261 \\
\hline $\begin{array}{l}\text { Średnia kwota mandatu wystawionego na } \\
\text { przewoźnika zagranicznego }\end{array}$ & 267 & 265 \\
\hline
\end{tabular}

Źródło: Sprawozdanie Głównego Inspektora Transportu Drogowego za rok 2010, 2011; obliczenia własne.

Kontrole drogowe wsparte są fotoradarami. Rozmieszczenie fotoradarów i inspektorów w poszczególnych województwach przedstawia Tabela 5.

Tabela 5. Rozmieszczenie kamer i fotoradarów w Polsce

(stan na 31 III 2013 r.)

\begin{tabular}{|l|c|}
\hline \multicolumn{1}{|c|}{ Województwo } & Liczba kamer i fotoradarów \\
\hline dolnośląskie & 18 \\
\hline kujawsko-pomorskie & 14 \\
\hline lubelskie & 20 \\
\hline lubuskie & 18 \\
\hline łódzkie & 18 \\
\hline małopolskie & 16 \\
\hline mazowieckie & 35 \\
\hline opolskie & 9 \\
\hline podkarpackie & 15 \\
\hline podlaskie & 19 \\
\hline pomorskie & 18 \\
\hline śląskie & 23 \\
\hline świętokrzyskie & 8 \\
\hline warmińsko-mazurskie & 14 \\
\hline wielkopolskie & 39 \\
\hline zachodniopomorskie & 16 \\
\hline
\end{tabular}

Źródło: Żółciak 2013: A3.

Według stanu na 31 III 2013 r. w Polsce było zamontowanych 375 fotoradarów stacjonarnych oraz 236 gminnych (Żółciak 2013: A3), co daje 16 urządzeń/10 tys. km dróg (dla porównania w Wielkiej Brytanii - 57, Francji - 25, Holandii - 66 na 10 tys. km dróg). 
Z danych Europen Road Statistics wynika, że wdrożenie automatycznego nadzoru nad ruchem drogowym spowodowało, że w latach $2001-2009$ zredukowała się liczba ofiar śmiertelnych np. we Francji z 8,1 tys. do 4,3 tys.; we Włoszech z 7,1 tys. do 4,2 tys., a w Holandii z 933 do 644 osób rocznie.

\section{UBEZPIECZENIOWY PUNKT WIDZENIA}

Z powyższych rozważań wynika, że samochody ciężarowe kierowane są najczęściej przez zawodowych kierowców zwanych flotowymi. Obsługują oni zbiór pojazdów (flotę) dla celów handlowych bądź usługowych. Pracownicy ci traktują swoje pojazdy jako narzędzie pracy, a kierowanie nimi jest realizacją zadań służbowych. Bardzo często zdarza się, że kierowcy flotowi rocznie przejeżdżają kilkadziesiąt tysięcy kilometrów. Wypadki drogowe z udziałem kierowców flotowych są więc przedmiotem szczególnej troski ze strony menedżerów przedsiębiorstw. W wypadkach często są ofiary śmiertelne i ranne, a także uszkodzony zostaje przewożony majątek przedsiębiorstw. W wypadkach poszkodowani są często sami kierowcy flotowi. Dane zawarte w tab. 1 pokazują, jak wiele jest ofiar śmiertelnych i rannych. $Z$ badań przeprowadzonych w latach 2006-2007 r. wynika, że:

- ok. 52\% kierowców prowadziło ciężkie pojazdy pow. 3,5 ton;

- poszkodowani kierowcy flotowi lekkich pojazdów transportowych stanowili ok. 62\%;

- wśród poszkodowanych kierowców zawodowych mężczyźni stanowili ok. $98,5 \%$;

- wypadki ze skutkiem śmiertelnym zdarzają się częściej mężczyznom niż kobietom (Żużewicz, Konarska, Łuczak 2010: 4-8).

Wszystkie pojazdy ciężarowe powinny być ubezpieczone obowiązkowym ubezpieczeniem odpowiedzialności cywilnej posiadaczy pojazdów mechanicznych. Dzięki zebranym składkom z tego ubezpieczenia zakłady ubezpieczeń powinny być w stanie pokryć wszelkie roszczenia z tytułu wypadków z udziałem pojazdów ciężarowych. Całość skutków wypadków drogowych z udziałem pojazdów ciężarowych możemy podzielić na dwie grupy: szkody osobowe i szkody majątkowe ${ }^{6}$. Zmniejszenie liczby wypadków z udziałem pojazdów ciężarowych przyczynia się do zmniejszenia roszczeń poszkodowanych a także kosztów społecznych (Pasieczny 1999: 22-24.).

Warto także zwrócić uwagę, że zmniejszeniu ulegają tzw. koszty pośrednie, do których zaliczyć możemy m.in.:

\footnotetext{
${ }^{6}$ Szkody spowodowane przez ruch drogowy szeroko opisane są w literaturze ubezpieczeniowej i czasopismach specjalistycznych.
} 
- koszty otoczenia miejsca wypadku;

- koszty obsługi prawnej;

- koszty strat w produkcji, usługach a także w produkcie krajowym brutto;

- rekompensaty dla osób pośrednio uczestniczących w wypadkach (znajomi, krewni);

- zmniejszenie wysokości podatków;

- straty spowodowane opóźnieniami dostaw.

Dodatkowo ulegają zmniejszeniu roszczenia związane $\mathrm{z}$ uszkodzonym, przewożonym mieniem. Wszystkie powyższe tendencje powinny znaleźć swoje odzwierciedlenie w zwyżkach i obniżkach składek ubezpieczeniowych (Dąbrowska-Loranc 2003: 27-37). Również maleje liczba sytuacji konfliktowych między zakładem ubezpieczeń a posiadaczem pojazdu (Szymczak 2003: 293301; Ptaszyński 2003: 239-253) w zakresie kosztów likwidacji szkód. Dalsze zaostrzenie przepisów drogowych od 2015 roku powinno przyczynić się do wzrostu bezpieczeństwa ruchu drogowego a także zmniejszenia roszczeń odszkodowawczych.

\section{ZAKOŃCZENIE I WNIOSKI}

Powołanie Inspekcji Transportu Drogowego miało na celu zwiększenie bezpieczeństwa w ruchu drogowym. Z przeprowadzonych rozważań wynikają następujące wnioski:

1) corocznie przeprowadzana jest dostatecznie duża liczba kontroli pojazdów ciężarowych poruszających się po polskich drogach,

2) dzięki rygorystycznym kontrolom stopniowo zmniejsza się liczba wypadków z udziałem samochodów ciężarowych,

3) bezpośrednią przyczyną zmniejszania się liczby poszkodowanych w ruchu samochodów ciężarowych są ostre środki administracyjne i karne.

Podjęta problematyka funkcjonowania ITD w Polsce nie została wyczerpana, lecz jedynie zasygnalizowana. Konieczne są dalsze badania, które powinny być ukierunkowane na analizę wartości roszczeń z wypadków z udziałem pojazdów ciężarowych.

\section{BIBLIOGRAFIA}

Burski Z., Krasowski E. (2009), Analiza realizacji standardów ustawy o transporcie drogowym $R P$ w aspekcie przewozu osobowego, „Motrol”, 11B, s. 32.

Dąbrowska-Loranc M. (2013), Rola towarzystw ubezpieczeniowych w procesie poprawy bezpieczeństwa ruchu drogowego, materiały z I Konferencji Rozwój techniki samochodowej a ubezpieczenia komunikacyjne, Radom 17 VI, s. 27-37. 
Duś A., Duś-Pilarz J. (2009), Możliwości rejestracyjne tachografów cyfrowych i ich przydatność do analiz wypadków drogowych, ,Paragraf na drodze”, numer specjalny, s. 263-274.

Inspektor drogowy zamiast policjanta? (2011) „Logistyka jakości”, nr 1-2, s. 76-77.

Kacprzyk R. (2010), Kontrole przewozów ADR prowadzone przez Inspekcję Transportu Drogowego na przykładzie województwa śląskiego. Aspekt ochrony środowiska w pracy inspektora transportu drogowego, Bezpieczeństwo w transporcie drogowym towarów niebezpiecznych $w$ aspekcie ochrony środowiska, Materiały z ogólnopolskiego seminarium zorganizowanego w dniach 27-28 maja 2010 w Szkole Aspirantów PSP w Krakowie.

Kazimierowski P. (2009), Ocena stanu bezpieczeństwa ruchu kolejowego w roku 2007, „Transport i Komunikacja”, nr 1, s. 22.

Pasieczny W. (1999), Społeczne koszty wypadków drogowych, „BRD”, nr 9, s. 22-24.

Ptaszyński P. (2003), Koszty naprawy pojazdu a wysokość szkody w pojeździe, materiały z I Konferencji Rozwój techniki samochodowej a ubezpieczenia komunikacyjne, Radom 17 VI, s. 239-253.

Reichel K., Nowakowski Z. (2006), Pojęcie wypadku drogowego i systemu ewidencji, „Zeszyty Naukowe Politechniki Rzeszowskiej" nr 7, s. 103.

Ryś D. (2012), Pojazdy przeciążone na polskich drogach, „Drogownictwo”, nr 12, s. 400-404.

Sprawozdanie Głównego Inspektora Transportu Drogowego za rok 2010, 2011, 2012.

Szwed I. (2014), Preselekcyjny system ważenia a kontrola ITD w firmie, „Transport i Spedycja”, nr 2, s. 40.

Szymaniak P. (2013), Sędziowie przeciwni większym uprawnieniom ITD, „Dziennik Gazeta Prawna", 6 maja.

Szymczak B. (2003), Wysokość roszczenia a odszkodowanie, materiały z I Konferencji Rozwój techniki samochodowej a ubezpieczenia komunikacyjne, Radom 17 VI, s. 293-301.

Wardęga R. (2010), Analiza nacisków osi pojazdów ciężarowych na nawierzchnie drogowe, „Drogownictwo", nr 11, s. 400-401.

Ważenie pojazdów i przejazdy ponadnormatywne na drogach publicznych - problem nie tylko prawny, „Polskie drogi”, nr 7-8/2002, s. 41.

Wypadki drogowe w 2013 r., „Miesięcznik Ubezpieczeniowy” 6/2014, wkładka.

Żaczek R. (2014), Inspekcja Drogowa może kontrolować każdego kierowcę, „Dziennik Gazeta Prawna", 18 listopada.

Żółciak T. (2013), Mapy ryzyka pomoga w montowaniu kamer i fotoradarów, „Dziennik Gazeta Prawna". 13 marca, nr 51 (3441), s. A3.

Żużewicz K, Konarska M., Łuczak A. (2010), Problematyka wypadkowości kierowców flotowych, „Bezpieczeństwo Pracy”, nr 9, s. 4-8.

\section{Wybrane akty prawne}

Rozporządzenie Ministra Infrastruktury z dnia 29 września 2004 r. w sprawie wspótdziatania straży ochrony kolei, z Policją, Straża Graniczna i Inspekcja Transportu Drogowego, Dziennik Ustaw nr 223/2004 poz. 2262.

Zarzązenie Nr 12/2011 Gtównego Inspektora Transportu Drogowego zdnia 16 lutego 2011 r. w sprawie nadania regulaminu organizacyjnego Gtównemu Inspektorowi Transportu Drogowego, Dziennik Urzędowy Ministra Infrastruktury nr 2/2011 poz. 11.

Zarządzenie Nr 21/2011 Głównego Inspektora Transportu Drogowego z 31 III 2011 r. w sprawie określenia wysokości współczynnika ryzyka, występowania naruszeń dotyczacych czasu prowadzenia pojazdu, obowiazkowych przerw i czasu odpoczynku kierowców za rok 2010, Dziennik Urzędowy Ministra Infrastruktury nr 4/2011 poz. 26.

Obwieszczenie Ministra Transportu z 8 lipca 2007 r. w sprawie szczegółowych czynności organów w sprawach zwiazanych $z$ dopuszczeniem pojazdu do ruchu oraz wzorców dokumentów w tych sprawach (Dz.U. 2007 poz. 968 z poźn. zm.). 
Stanisław Wieteska

THE ROAD TRANSPORT INSPECTION ROLE IN REDUCING TRAFFIC ACCIDENTS IN POLAND

\begin{abstract}
Road Transport Inspection (ITD) was established in 2001. Its aim is to increase traffic safety. This article aims to answer the question to what extent the appointment of ITD contributes to improving road safety in Poland. In the article, in addition to discussion the objectives of the organization and scale of accidents involving heavy vehicles, we discuss quantitative status checks carried out. We are observing the period 2005-2012. The article shows that with strong administrative decisions and criminal proceedings, the number of accidents and their consequences involving heavy duty motor vehicles is reduced.
\end{abstract}

Keywords: vehicles, accidents, Road Transport Inspection (ITD).

JEL: R42. 